\title{
ELECTRON PROBE ANALYSIS OF SILICON AND OTHER ELEMENTS IN LEAF EPIDERMAL CELLS OF THE RICE PLANT (ORYZA SATIVA L.) ${ }^{1}$
}

\author{
Sarvjit L. Soni, Peter B. Kaufman, and Wilbur C. Bigelow \\ Department of Botany and Department of Chemical and Metallurgical Engineering, \\ University of Michigan, Ann Arbor 48104
}

\section{A B S T R A C T}

By means of electron probe analysis, the effects of significant amounts of accumulation of silicon on the accumulation of calcium, potassium, magnesium, manganese, phosphorous, iron, and sodium in the silica cells of rice leaves are described. The silica cells of both the surfaces of the leaf blade and leaf sheath were studied. Silicon accumulation in the silica cells appears to decrease the amount of accumulation of potassium on both the surfaces of the leaf blade and sheath. The effect of significant amounts of silicon accumulation on the accumulation of other elements in a particular cell varies in different organs or on different surfaces of the organ of the same plant. Magnesium, manganese, iron, and phosphorus could not be detected in the adaxial epidermis of the leaf sheath and magnesium and iron in the adaxial epidermis of the leaf blade. Manganese, magnesium, and phosphorus were not detected in the abaxial epidermis of the leaf blade nor iron in the abaxial epidermis of the leaf sheath. Sodium was not revealed in either surface of the leaf blade and leaf sheath. Possible mechanisms for the effects of silicon accumulation on the accumulation of these elements in rice leaf epidermal cells are discussed.

THE EFFECTS of the deficiency or addition of silicon to the culture medium on the accumulation of other elements, particularly $\mathrm{Mn}$ and $\mathrm{Fe}$, have been extensively studied in rice plants (Islam and Saha, 1969; Lewin and Reimann, 1969). However, little work has been performed on the effects of accumulation of significant quantities of silicon on the deposition of other elements, particularly in the silica cells of plants. This may be due to the lack of appropriate techniques to measure the relative amounts of various elements in a particular cell. Electron probe analysis ${ }^{2}$ permits the simultaneous detection of several elements in a microstructure (Andersen, 1967). Using EPA, Soni, Kaufman, and Bigelow (in press, a, b), reported that the accumulation of significant amounts of silicon in the silica cell appears to decrease the accumulation of $\mathrm{K}$ and to increase the accumulation of certain other elements in the leaf epidermal cells of Cyperus alternifolius and of Avena sativa.

In this study, we examined the silica cells and adjacent cells of the abaxial and adaxial epidermis of the leaf blade and sheath of the rice plant

${ }^{1}$ Received for publication 22 March 1971.

We thank Fred Bleicher, Paul Nesbitt, and Jon Rosen for their technical assistance on the electron probe; $\mathrm{Mr}$. Louis Martonyi for his photographic work; and Dr. John Mastenbroek, Plant Breeder, California Rice Experiment Station, Biggs, California for the supply of rice seeds.

2 This term, electron probe analysis, will be designated as EPA throughout the remainder of this paper.
(Oryza sativa L.) for the relative amounts of certain elements, such as $\mathrm{Ca}, \mathrm{K}, \mathrm{Mg}, \mathrm{Mn}, \mathrm{Fe}, \mathrm{P}$, and $\mathrm{Na}$, associated with high and low amounts of silicon. This study was undertaken to determine whether the accumulation of significant quantities of silicon affects the accumulation of these elements.

Materials AND Methods-Seeds of Oryza sativa cv. 'Colusa' were obtained from the Rice Experiment Station, University of California, Biggs.

The seeds were sterilized with $10 \%$ "Clorox" for $2 \mathrm{~min}$ and washed thoroughly with distilled water. These were then placed in distilled water and incubated in the dark at $30 \mathrm{C}$ for $24 \mathrm{hr}$. After this, the seeds were placed in plastic trays containing vermiculite and incubated at $30 \mathrm{C}$ in the dark for 5 days. The seedlings were transferred to 1-gal porcelain crocks containing clay soil and grown in the greenhouse with a photoperiod of $18 \mathrm{hr}$ light and $6 \mathrm{hr}$ dark. The average day temperature was $26 \mathrm{C}$ and night temperature 22 C. Mature leaves, 4-6, were excised and used for this study. Except for minor modifications, the preparation of tissue for EPA is the same as cited in Kaufman, Bigelow, Petering, and Drogosz (1969) and Soni et al. (in press, a, b) : (1) thin epidermal peels were made with the help of a razor blade of the abaxial and adaxial surfaces from different locations within $6 \mathrm{~cm}$ from the leaf tip as well as from the base of the leaf blade; 
TABLE 1. Point-count data for silicon and other elements in the leaf blade and leaf sheath epidermis of rice

\begin{tabular}{|c|c|c|c|c|c|}
\hline \multirow[b]{3}{*}{ Element } & \multirow[b]{3}{*}{ Type of Cell } & \multicolumn{4}{|c|}{ Part of Plant } \\
\hline & & \multicolumn{2}{|c|}{$\begin{array}{c}\text { Leaf Blade } \\
\text { Epidermis }\end{array}$} & \multicolumn{2}{|c|}{$\begin{array}{l}\text { Leaf Sheath } \\
\text { Epidermis }\end{array}$} \\
\hline & & Abaxial & Adaxial & Abaxial & Adaxial \\
\hline $\mathrm{Si}$ & $\begin{array}{l}\text { Silica Cel1 } \\
\text { Other Cells }\end{array}$ & $\begin{array}{r}3599 \\
998\end{array}$ & $\begin{array}{r}3055 \\
734\end{array}$ & $\begin{array}{r}7389 \\
47\end{array}$ & $\begin{array}{r}1798 \\
79\end{array}$ \\
\hline $\mathrm{K}$ & $\begin{array}{l}\text { Silica Cell" } \\
\text { Other Cells" }\end{array}$ & $\begin{array}{l}116 \\
242\end{array}$ & $\begin{array}{r}560 \\
1235\end{array}$ & $\begin{array}{l}448 \\
724\end{array}$ & $\begin{array}{l}111 \\
161\end{array}$ \\
\hline $\mathrm{Ca}$ & $\begin{array}{l}\text { Silica Cell' } \\
\text { Other Cells" }\end{array}$ & $\begin{array}{r}35 \\
108\end{array}$ & $\begin{array}{r}18 \\
260\end{array}$ & $\begin{array}{l}335 \\
121\end{array}$ & $\begin{array}{l}19 \\
14\end{array}$ \\
\hline $\mathrm{Mg}$ & $\begin{array}{l}\text { Silica Cell }{ }^{\mathrm{b}} \\
\text { Other Cells }\end{array}$ & $\begin{array}{l}\text { n.d. } \\
\text { n.d. }\end{array}$ & $\begin{array}{l}\text { n.d. } \\
\text { n.d. }\end{array}$ & $\begin{array}{l}27 \\
22\end{array}$ & $\begin{array}{l}\text { n.d. } \\
\text { n.d. }\end{array}$ \\
\hline $\mathrm{Mn}$ & $\begin{array}{l}\text { Silica Cell } \\
\text { Other Cells }\end{array}$ & $\begin{array}{l}\text { n.d. } \\
\text { n.d. }\end{array}$ & $\begin{array}{r}6 \\
\text { n.d. }\end{array}$ & $\begin{array}{r}7 \\
\text { n.d. }\end{array}$ & $\begin{array}{l}\text { n.d. } \\
\text { n.d. }\end{array}$ \\
\hline $\mathrm{Fe}$ & $\begin{array}{l}\text { Silica Cell }{ }^{\mathrm{b}} \\
\text { Other Cells }\end{array}$ & $\begin{array}{r}7 \\
64\end{array}$ & $\begin{array}{l}\text { n.d. } \\
\text { n.d. }\end{array}$ & $\begin{array}{l}\text { n.d. } \\
\text { n.d. }\end{array}$ & $\begin{array}{l}\text { n.d. } \\
\text { n.d. }\end{array}$ \\
\hline $\mathbf{P}$ & $\begin{array}{l}\text { Silica Cell }{ }^{1} \\
\text { Other Cells }\end{array}$ & $\begin{array}{l}\text { n.d. } \\
\text { n.d. }\end{array}$ & $\begin{array}{r}\text { n.d. } \\
6\end{array}$ & $\begin{array}{l}9 \\
9\end{array}$ & $\begin{array}{l}\text { n.d. } \\
\text { n.d. }\end{array}$ \\
\hline $\mathrm{Na}$ & $\begin{array}{l}\text { Silica Cell }{ }^{\mathrm{b}} \\
\text { Other Cells }^{\mathrm{c}}\end{array}$ & $\begin{array}{l}\text { n.d. } \\
\text { n.d. }\end{array}$ & $\begin{array}{l}\text { n.d. } \\
\text { n.d. }\end{array}$ & $\begin{array}{l}\text { n.d. } \\
\text { n.d. }\end{array}$ & $\begin{array}{l}\text { n.d. } \\
\text { n.d. }\end{array}$ \\
\hline
\end{tabular}

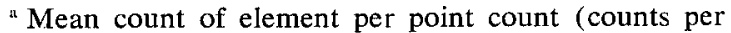
second) after subtracting the background count.

b Three loci per silica cell of three silica cells examined to obtain an average for a particular cell.

"Mean count of the element in the adjacent epidermal cells not accumulating significant quantities of silicon. n.d. $=$ none detected.

similarly, the peels were made within $6 \mathrm{~cm}$ of the base of the leaf sheath; (2) tissue pieces were placed in aluminum foil envelopes $2 \mathrm{~cm}$ square, immediately frozen in liquid nitrogen, and then dried at $0 \mathrm{C}$ in a Virtis automatic freeze dryer (No. 10-010) for $2 \mathrm{hr}$; (3) the dried pieces were mounted on polished copper squares with electrically conductive silver paint, covered by evaporating a thin layer of carbon upon them, and stored in a desiccator until examination in the probe.

The electron probe (Applied Research Laboratories, model EMX-SM) was operated at 15 $\mathrm{kev}$, with a beam current of $0.5 \mu \mathrm{amps}$, an emission current of $150 \mu \mathrm{amps}$, and spot diam $=0.5 \mu$, giving an electron beam penetration into the tissue of about $15 \mu \mathrm{m}$. The sample current was $0.02 \mu \mathrm{amps}$. The X-ray spectrometer was peaked for the first order silicon $\mathrm{K}$ alpha line with an ammonium dihydrogen phosphate crystal. Secondary electron scanning images were employed to examine the tissue and to select cells for analysis. Qualitative determinations of silicon distribution were made by line scanning, and the data are expressed as counts per second (cps). Pointcount data were obtained from an average of three locations per cell. At each locus, counts were made for 50 seconds and averaged. Because of the problem of measuring oxygen directly with the probe, especially in biological material, we only measured silicon ( $\mathrm{Si}$ ).

For EPA study of other elements the spectrometers were peaked for the first order $\mathrm{K}$ alpha wavelengths with a lithium flouride (LiF) crystal for $\mathrm{K}, \mathrm{Ca}, \mathrm{Fe}$, and $\mathrm{Mn}$, a potassium acid pthalate (KAP) crystal for $\mathrm{Na}$ and $\mathrm{Mn}$, and an ammonium dihydrogen phosphate crystal for $\mathbf{P}$.

Following Lipps and Ribbe (1967), the statistical tests for elemental detection were applied to the data in Table 1:

$\mathrm{N}_{\mathrm{T}}<\left(\overline{\mathrm{N}}_{\mathrm{I}}+\overline{\mathrm{N}}_{\mathrm{B}^{\frac{1}{2}}}\right)$, the element is probably not present at the limit of detectability; $\left(\overline{\mathrm{N}}_{\mathrm{B}}+\overline{\mathrm{N}}_{\mathrm{B}^{\frac{1}{2}}}\right)<$ $\mathrm{N}_{\mathrm{T}}<\left(\overline{\mathrm{N}}_{\mathrm{B}}+3 \overline{\mathrm{N}}_{\mathrm{B}^{\frac{1}{2}}}\right)$, the element is probably present; and $\mathrm{N}_{\mathrm{T}}>\left(\overline{\mathrm{N}}_{\mathrm{B}}+3 \overline{\mathrm{N}}_{\mathrm{B}}^{\frac{1}{2}}\right)$, the element is definitely present.

$N_{T}$ is the total number of counts for a particular element; $N_{B}$ is the average off-wavelength background counts that were measured over identical time intervals on the same sample.

OBSERVATIONS-Silicon-An EPA study of the silica cells (Fig. 1) on both the surfaces of the leaf blade and leaf sheath reveals significant amounts of silicon to be present in these cells (Fig. 2). The distribution of silicon in the silica cell (Fig. 5) in transverse (Fig. 6) and longitudinal directions (Fig. 7) as shown by line scanning as well as by point counting data (upper and lower edges-2919, 2999 cps; middle region$3269 \mathrm{cps}$ ) is not uniform. Similarly, Kaufman et al. (1969) and Soni et al. (in press, a) reported that the distribution of silicon is not uniform in the silica cells of the internode and leaf sheath of Avena sativa. Silica cells on the abaxial surfaces of the leaf blade and sheath of the rice plant appear to have a larger quantity of silicon than those on the adaxial surfaces (Table 1). The silica cells on the abaxial surface of the leaf sheath seem to have a significantly greater accumulation of silicon than those on the abaxial surface of the leaf blade (Table 1).

No significant amounts of silicon were detected in the cork cells as was also reported by Kaufman et al. (1969) for the internodal epidermal cells in Avena and the leaf epidermal cells of Avena by Soni et al. (in press, a).

Potassium-This semi-quantitative analysis indicates that the silica cells and epidermal cells on the adaxial surface of the leaf blade have a larger quantity of potassium than comparable cells on the abaxial epidermis of the leaf blade and both the surfaces of the leaf sheath. On both surfaces of the leaf blade and sheath of the rice plant (Table 1), the relative amount of potassium in the silica cells is less than in adjoining epidermal cells with no significant amounts of silicon. This decreasing effect of high silicon levels on potas- 

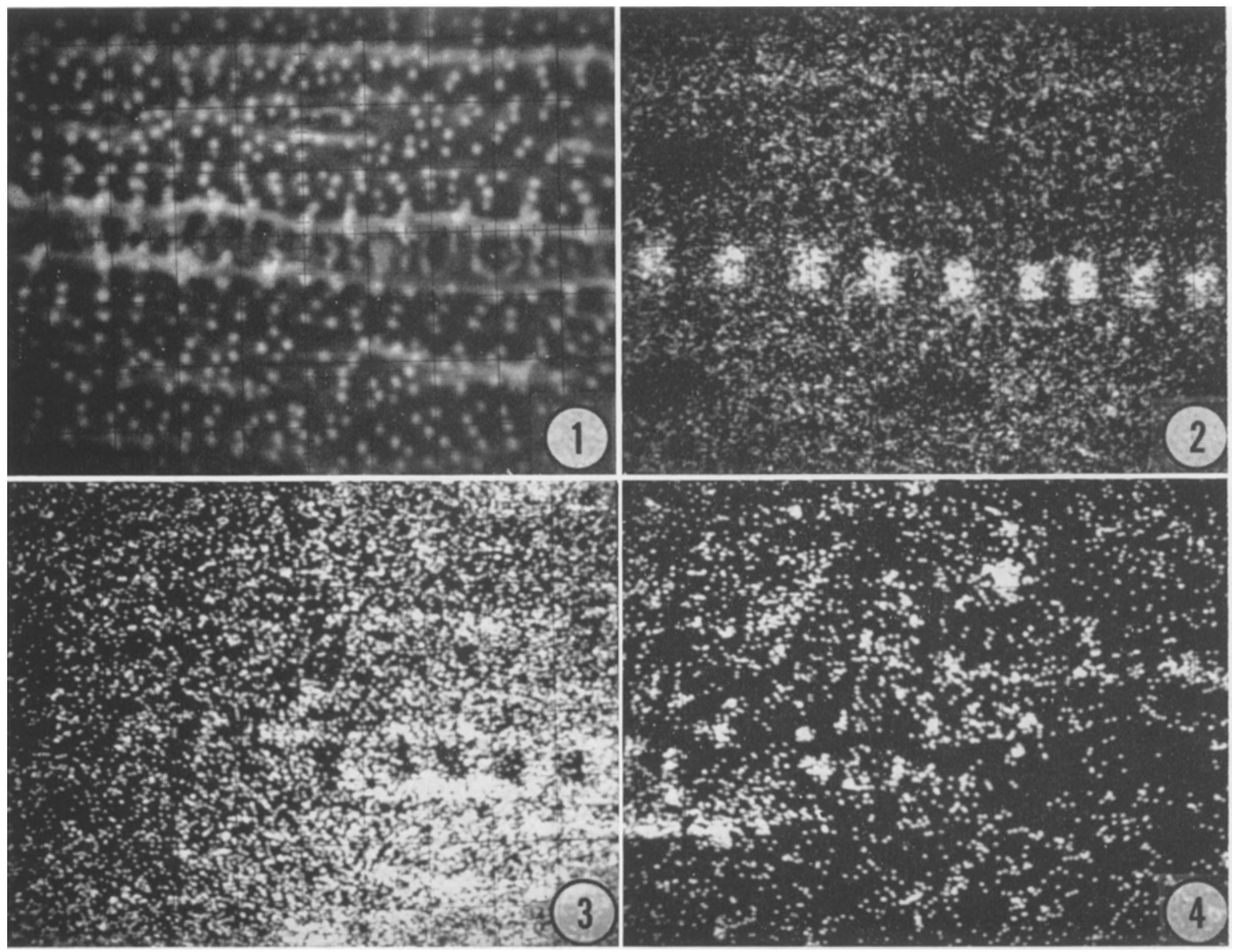

Fig. 1-4. Scans from an area of the adaxial epidermis of the leaf blade. $\times 500 .-$ Fig. 1. Secondary electron image.-Fig. 2-4. X-ray images for $\mathrm{Si}(\mathrm{K}), \mathrm{K}(\mathrm{K})$, and $\mathrm{Ca}(\mathrm{K})$, respectively. The horizontal row of brightly contrasted areas in Fig. 2 corresponds to silica cells with high levels of silicon. Silica cells (cf Fig. 2, 3) accumulate low quantity of $\mathrm{K}$.

sium accumulation in the silica cells (Fig. 1) is clearly shown by comparing the X-ray images of $\mathrm{Si}$ and $\mathrm{K}$ (cf Fig. 2,3).

Calcium-The point-count data in Table 1 for calcium indicate that the relative amount of accumulation of calcium and silicon in the silica cells on both the surfaces of the leaf blade (Fig. 4) and sheath of the rice plant show less $\mathrm{Ca}$ as compared to adjoining epidermal cells with no significant amounts of silicon. Data in Table 1 also suggest much less accumulation of calcium in the epidermal cells of the adaxial surface as compared to the abaxial surface of the leaf sheath and both surfaces of the leaf blade.

Magnesium-Point-count data in Table 1 suggest that in the leaf sheath the amount of magnesium accumulated in the silica cells is slightly greater than in the adjacent cells (with no significant amount of silicon) on the abaxial surface. Magnesium was not detected in these same types of cells on the adaxial surface of the leaf sheath nor on either surface of the leaf blade.

Iron and Manganese-With EPA iron could not be detected in the silica cells nor in adjoining epidermal cells on either surface of the leaf sheath or the adaxial epidermis of the leaf blade. On the abaxial surface of the leaf blade this analysis detected the presence of iron both in the silica cells and in the adjoining epidermal cells. The point-count data in Table 1 suggest that there is a greater accumulation of iron in adjoining epidermal cells with no significant amount of silicon than in the silica cells themselves on the abaxial surface of the leaf blade. In contrast, the silica cells of the leaf epidermis of Cyperus alternifolius accumulate larger amounts of iron than the adjoining epidermal cells (Soni et al., in press, b).

Manganese could be detected only in silica cells of the adaxial epidermis of leaf sheath and blade (Table 1). 

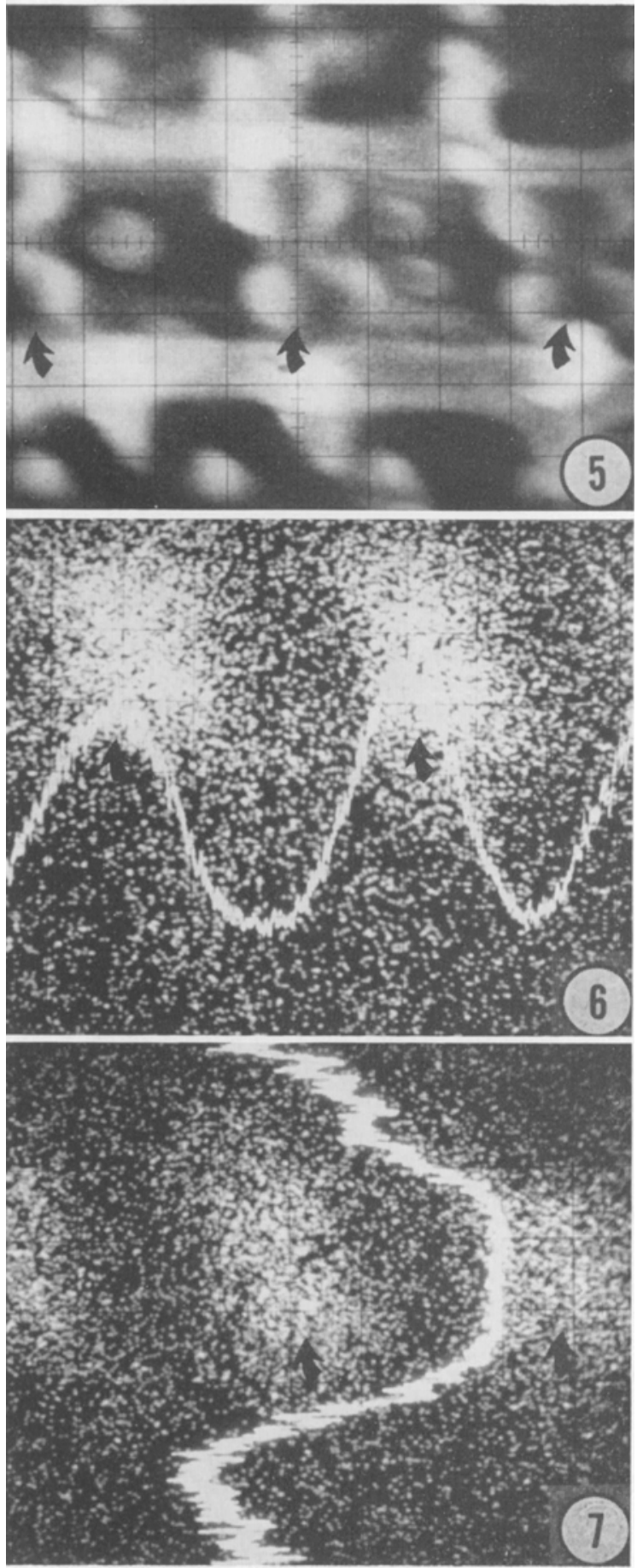

Fig. 5-7. Scans from an area of the adaxial epidermis of the leaf blade. $\times 2,500$.-Fig. 5. Secondary electron image. Arrows point to dumbbell-shaped areas which are the silica cells. Fig. 6, 7. X-ray images for $\mathrm{Si}(\mathrm{K})$ and line scans for silicon through the silica cells, longitudinally and transversely, respectively; the brightly contrasted areas correspond to silica cells (arrows, corresponding to same loci with arrows in Fig. 5).
Phosphorus-The amount of phosphorus in the silica cells and in adjoining cells with no significant amount of silicon is the same on the abaxial epidermis of the leaf sheath. Phosphorus could not be detected in these cells either in the abaxial epidermis of the leaf blade or in the adaxial epidermis of the leaf sheath. In the adaxial epidermis of the leaf blade phosphorus was detected in the adjoining cells but not in the silica cells.

Sodium-This element could not be detected in the epidermal and silica cells on either surface of leaf blade and sheath.

Discussion-Silicon is considered to be present in silica cells in the form of its oxide $\left(\mathrm{SiO}_{2}\right)$ and is deposited as opal or, primarily, as silica gel $\left(\mathrm{SiO}_{2} \cdot \mathrm{nH}_{2} \mathrm{O}\right)$. Light and electron microscopy studies (Blackman, 1968; Kaufman, Petering, and Smith, 1970; Sangster, 1970) have revealed that the silica cell during its development loses its nucleus; it then becames filled with fibrillar material and osmiophilic droplets, presumably breakdown products of membranes and organelles; and finally, silica is deposited as long chains of silica bodies in the lumen of the cell. The mechanism of silica accumulation in higher plants is not known. It has been postulated to be a passive process by Jones and Handreck (1965) and by Frey-Wyssling (1930). Physicochemical factors such as the characteristics of silicic acid sols, the presence of polyvalent metal ions, the chemical nature of senescent cytoplasm, and electrokinetic properties in the cell may have favored the accumulation of silica (Sangster, 1970). Alternatively, the process may be an active one as experimentally shown for diatoms (Lewin and Reimann, 1969).

Soni et al. (in press, a, b) reported a decrease in potassium accumulation in silica cells, as compared with other epidermal cells, in leaves of Avena sativa and Cyperus alternifolius. In the present study the same effect of high silicon levels on potassium accumulation in the silica cells of both surfaces of the leaf blade and leaf sheath of the rice plant is observed. Islam and Saha (1969) reported that the addition of silicon along with other nutrients to the culture solution decreases the potassium uptake of rice plants. The decreasing effect of silicon on potassium accumulation in silica cells could be due to the breakdown of cytoplasm and nucleus in these cells. This would effectively block any active accumulation of potassium ions by the vacuoles, which obviously are destroyed in mature silica cells. The mechanism by which this exclusion occurs should be studied further.

The accumulation of calcium is also decreased by the accumulation of silicon in the silica cells of the rice plant. This corroborates findings reported earlier in the special silica cells of the leaf 
epidermis of Avena sativa (Soni et al., in press, a). In contrast, the silica cells reveal more calcium than adjoining epidermal cells with no significant amount of silicon in the leaf epidermis of Cyperus alternifolius (Soni et al., in press, b). Islam and Saha (1969) found an increase of calcium uptake when silicon was included with other nutrients in the culture solution.

The larger quantity of magnesium in the silica cells than in the adjoining epidermal cells of the abaxial epidermis of the leaf sheath of the rice plant indicates that the accumulation of silicon causes a slight but significant increase of this element. A similar relationship was reported in the leaf epidermis of Cyperus alternifolius (Soni et al., in press, b). In other work (Islam and Saha, 1969), the uptake of magnesium was found to be increased by silicon in the culture solution. Because there was no detectable magnesium in the silica cells and epidermal cells on either surface of the leaf blade nor on the adaxial surface of the leaf sheath, the relative amounts of these elements ( $\mathrm{Mg}$ and $\mathrm{Si}$ ) could not be studied.

Iron and manganese could not be detected in the sclerenchyma cells and special silica cells of the leaf epidermis of Avena sativa (Soni et al., in press, a); these cells have significant amounts of silicon. The accumulation of iron and manganese in leaves of silicon-deficient rice plants seems to be striking (Lewin and Reimann, 1969) and therefore supports our findings here. It appears that the accumulation of iron and manganese may be different in different surfaces of different organs of the rice plant and that the accumulation of silicon in a particular cell or tissue may enhance the accumulation of manganese and may suppress the accumulation of iron. Islam and Saha (1969) reported that silicon in the culture solution decreased the iron content of rice plants. However, the manganese content is irregular in one-monthold plants. In 2- and 6-month-old plants, the addition of increasing amounts of silicon decreased the manganese content.

In the rice plant there does not seem to be any effect of silicon accumulation on the accumulation of phosphorus except for a suppressing effect of the former on the latter in the adaxial epidermis of the leaf blade (Table 1). In contrast, the accumulation of phosphorus is increased by the accumulation of silicon in the leaf epidermis of Cyperus alternifolius (Soni et al., in press, b). In rice plants, Islam and Saha (1969) reported an increase in phosphorus with the addition of silicon to the nutrient solution. Using ${ }^{32} \mathrm{P}$, Okuda and Takahashi (1965) found a retarding effect of silicon on the uptake of phosphorus.

Because of the absence of any detectable sodium in the epidermal cells of the rice plant, there may not be any effect of silicon on the accumulation of this element.

The effect of silicon on decreased accumulation of potassium and calcium in the silica-rich cells may be due to the competition of silicon for ion accumulation sites. This competition could be a passive ion exchange process in the cell similar to that pertaining to soil colloids. Potassium and calcium could also be excluded by an active mechanism requiring the presence of intact membranes in the cell. If this is the case, silicon influx may occur passively in cells where membranes have broken down (silica cells) or involve an active mechanism where protoplasmic membranes are intact (trichomes and long epidermal cells).

\section{LITERATURE CITED}

ANDERSEN, C. A. 1967. An introduction to the electron probe microanalyzer and its application to biochemistry, p. 147-270. In Methods of biochemical analysis. Vol. 15. Interscience, New York.

Blackman, Elizabeth. 1968. The pattern and sequence of opaline silica deposition in rye (Secale cereale L.). Ann. Bot. 32: 207-218.

Frey-Wyssling, A. 1930. Über die Ausscheidung der Kieselsäure in der Pflanze. Ber. Deut. Bot. Ges. 48: 179-183.

IsLam, A., AND R. C. SaHA. 1969. Effects of silicon on the chemical composition of rice plants. Plant Soil 30: $446-458$.

Jones, L., AND K. Handreck. 1965. Studies of silica in the oat plant. III. Uptake of silica from soils by the plant. Plant Soil 23: 79-95.

Kaufman, P. B., W. C. Bigelow, L. B. Petering, and F. B. Drogosz. 1969. Silica in developing epidermal cells of Avena internodes: electron microprobe analysis. Science 166: 1015-1017.

L. B. Petering, and J. G. SMith. 1970. Ultrastructural development of cork-silica cell pairs in Avena internodal epidermis. Bot. Gaz. 131: 173185.

Lewin, J. C., ANd B. E. F. Reimann. 1969. Silicon and plant growth. Annu. Rev. Plant Physiol. 20: 289-304.

LipPS, J. H., AND P. H. RibBE. 1967. Electron probe microanalysis of planktonic foraminifera. J. Paleontol. 41: 492-496.

Okuda, A., and E. Takahashi. 1965. In The mineral nutrition of the rice plant, p. 123-146 (Proc. Symp. Int. Rice Res. Inst., Feb. 1964). John Hopkins Press, Baltimore.

SANGSTER, A. G. 1970. Intracellular silica deposition in mature and senescent leaves of Sieglingia decumbens (L.) Bernh. Ann. Bot. 34: 557-570.

Soni, S. L., P. B. Kaufman, and W. C. Bigelow. In press, a. Electron microprobe analysis of the distribution of silicon in leaf epidermal cells of the oat plant (Avena sativa L.). Phytomorphology.

, AND - In press, b. Electron microprobe analysis of silica cells in leaf epidermal cells of Cyperus alternifolius. Plant Soil. 